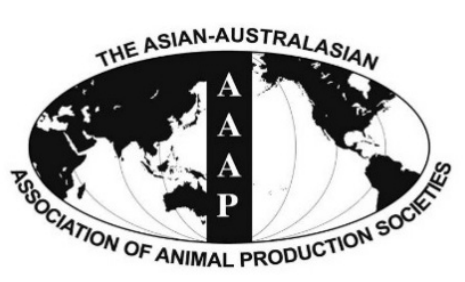

Open Access

Asian Australas. J. Anim. Sci.

Vol. 29, No. 12 : 1742-1747 December 2016

http://dx.doi.org/10.5713/ajas.15.0729

www.ajas.info

pISSN 1011-2367 elSSN 1976-5517

\title{
Effects of Dietary Methionine Levels on Choline Requirements of Starter White Pekin Ducks
}

\author{
Z. G. Wen ${ }^{1}$, J. Tang, M. Xie, P. L. Yang ${ }^{1}$, and S. S. Hou* \\ Institute of Animal Sciences, Chinese Academy of Agricultural Sciences, Beijing 100193, China
}

\begin{abstract}
A $2 \times 5$ factorial experiment, using 2 dietary methionine levels $(0.28 \%$ and $0.48 \%)$ and 5 dietary choline levels $(0,394$, $823,1,239$, and $1,743 \mathrm{mg} / \mathrm{kg}$ ), was conducted to study the effects of dietary methionine status on choline requirements of starter white Pekin ducks from 7 to 28 days of age. Four hundred eighty 7-d-old male White Pekin ducks were randomly allotted to ten dietary treatments, each containing 6 replicate pens with 8 birds per pen. At 28 d of age, weight gain, feed intake, and feed/gain were measured and the legs of all ducks from each pen were examined for incidence of perosis. Perosis and growth depression were observed in choline-deficient ducks and supplementation of choline reduced perosis and significantly increased weight gain and feed intake regardless of dietary methionine levels $(\mathrm{p}<0.05)$. In addition, significant positive effects of dietary methionine supplementation on weight gain, feed intake, and feed/gain were observed at any choline level ( $\mathrm{p}<0.05)$. Supplementation of $1,743 \mathrm{mg} / \mathrm{kg}$ choline in diets alleviated the depression of weight gain and feed intake caused by methionine deficiency at $0.28 \%$ methionine level. The interaction between choline and methionine influenced weight gain and feed intake of ducks $(\mathrm{p}<0.05)$. At $0.28 \%$ methionine level, $1,743 \mathrm{mg} / \mathrm{kg}$ choline group caused $4.92 \%$ and 3.23\% amount of improvement in weight gain and feed intake compared with 1,239 mg/kg choline group, respectively. According to the broken-line regression, the choline requirements of starter Pekin ducks for weight gain and feed intake were 1,472 and $1,424 \mathrm{mg} / \mathrm{kg}$ at $0.28 \%$ methionine level and 946 and $907 \mathrm{mg} / \mathrm{kg}$ at $0.48 \%$ methionine level, respectively. It suggested the choline recommendations of starter Pekin ducks on a semi-purified diet were $1448 \mathrm{mg} / \mathrm{kg}$ at $0.28 \%$ methionine level and $927 \mathrm{mg} / \mathrm{kg}$ at $0.48 \%$ methionine level, respectively. Compared with the adequate methionine level, menthionine deficiency markedly increased the choline requirements of ducks. (Key Words: Duck, Choline, Methionine, Growth Performance)
\end{abstract}

\section{INTRODUCTION}

Choline, a water-soluble vitamin, plays important roles in the synthesis of the membrane phospholipids (Hollenbeck, 2010), neurotransmitter synthesis (Blusztajn and Wurtman, 1983; Wessler et al., 2001) and methyl-group metabolism (Zeisel and Blusztajn, 1994). Poor growth, hepatic fatty infiltration, and perosis were all observed in choline-deficient Pekin ducks (Bernard and Demers, 1949; Wen et al., 2014). NRC (1994) provided choline recommendations for chickens, turkeys, geese, and quails, but the recommendation of this vitamin was missing for

\footnotetext{
* Corresponding Author: S. S. Hou. Tel: +86-10-62815832, Fax: +86-10-62815832, E-mail: houss@263.net

${ }^{1}$ Feed research institute, Chinese Academy of Agricultural Sciences, Beijing 100081, China.

Submitted Sept. 3, 2015; Revised Nov. 15, 2015; Accepted Jan. 7, 2016
}

ducks. At present, although the effects of different choline levels on growth performance of Tsaiya ducks was reported by Lien and Jan (1999), the data about the requirement of this vitamin was not given in their study and new literature on choline requirements of ducks was lacking until now.

On the other hand, choline is the methyl donor that provides the one-carbon unit in the conversion of homocysteine to methionine (Zeisel and Blusztajn, 1994). The interrelationship between choline and methionine remains a subject of ongoing debate. Ketola and Nesheim (1974) suggested that the choline requirement of chicks is elevated by high dietary methionine levels. However, some researchers reported more dietary choline was required when methionine is deficient in poultry (Miles et al., 1983; Harms and Miles, 1984). At present, studies on the interrelationship between methionine and choline in Pekin ducks are scarce and the effect of dietary methionine levels 
on choline requirements of ducks is not clear. Therefore, the objective was to estimate the choline requirements of white Pekin ducks with deficient and adequate methionine levels and to evaluate the effects of methionine status on the requirements of choline for ducks.

\section{MATERIALS AND METHODS}

This study was approved by the animal care and use committee of the Institute of Animal Sciences of Chinese Academy of Agricultural Sciences, and all efforts were made to minimize the suffering of animals.

\section{Birds and housing}

A $2 \times 5$ factorial experiment, using 2 dietary methionine levels $(0.28 \%$ and $0.48 \%)$ and 5 dietary choline levels $(0$, $394,823,1,239$, and $1,743 \mathrm{mg} / \mathrm{kg}$ ), was conducted to study the effects of methionine status on choline requirements in white Pekin ducks from 7 to 28 d of age. A total of 480 seven-d-old male White Pekin ducklings with average body weight of $132 \pm 3 \mathrm{~g}$ were randomly divided into ten dietary treatments, each containing 6 replicate pens with 8 birds per pen. These birds were kept in plastic-wire-floor pens (200 by 100 by $40 \mathrm{~cm}$ ) in an environmentally controlled experimental building. The temperature was kept at $28^{\circ} \mathrm{C}$ (at floor level) from 7 to $10 \mathrm{~d}$ of age, and then it was reduced gradually to room temperature until $28 \mathrm{~d}$ of age. All birds had free access to water and feed at any time and lighting was continuous. Water was provided by drip-nipple water supply lines and feed was fed in pellet form.

\section{Experimental diets}

The basal diet was formulated using corn starch and isolated soybean protein that were low in methionine and choline content (Table 1). To produce experimental diets, the basal diets were supplemented with different levels of $D L$-methionine $(0$ and $0.2 \%)$ and choline $(0,400,800$, 1,200 and $1,600 \mathrm{mg} / \mathrm{kg}$ ). Choline was added in the form of choline chloride (silica carrier, purity $\geq 50 \%$, Hebei Be-Long Feed Additive Co., Ltd, Heibe, China). The choline concentration was analyzed by ion exchange chromatography according to Zhai et al. (2013). In brief, powdered feed samples $(2 \mathrm{~g})$ were extracted with $25 \mathrm{~mL}$ of ultrapure water in a $50-\mathrm{mL}$ polypropylene centrifuge tube and homogenized for $1 \mathrm{~min}$. Then feed samples were extracted by using ultrasound bath for $30 \mathrm{~min}$ at $70^{\circ} \mathrm{C}$. The supernatant was transferred into a $50-\mathrm{mL}$ volumetric flask after extracts were centrifuged. After repeating the procedure, the volume of the supernatant was increased to $50 \mathrm{~mL}$ with ultrapure water. The supernatant was loaded into a plastic $2.5-\mathrm{mL}$ syringe and filtered by a $0.45-\mu \mathrm{m}$ filter membrane. This solution was then used for choline quantification by an ion chromatograph. Choline standards
Table 1. Ingredient composition and nutrient content of the basal diet ( $\%$ as-fed basis)

\begin{tabular}{lc}
\hline Item & Content \\
\hline Ingredient (\%) & 63.0 \\
Corn starch & 25.7 \\
Isolated soybean protein & 5.0 \\
Rice hull powder & 2.0 \\
Soybean oil & 2.2 \\
Dicalcium phosphate & 0.8 \\
Limestone meal & 1.0 \\
Premix ${ }^{1}$ & 0.3 \\
Sodium chloride & \\
Calculated values & 3,480 \\
Metabolizable energy ${ }^{2}(\mathrm{kcal} / \mathrm{kg})$ & 0.90 \\
Ca (\%) & 0.42 \\
Nonphytate P (\%) & \\
Analyzed values & \\
Crude protein $(\%)$ & 22.12 \\
Total lysine $(\%)$ & 1.29 \\
Total threonine $(\%)$ & 0.78 \\
Total tryptophan $(\%)$ & 0.20 \\
Total methionine $(\%)$ & 0.28 \\
Choline ${ }^{4}(\mathrm{mg} / \mathrm{kg})$ & 0 \\
\hline
\end{tabular}

${ }^{1}$ Premix provided the following per $\mathrm{kg}$ of diets: $\mathrm{Cu}, 10 \mathrm{mg}$; $\mathrm{Fe}, 60 \mathrm{mg}$; Zn, $60 \mathrm{mg}$; Mn, $80 \mathrm{mg}$; Mg, $500 \mathrm{mg}$; K, 2,000 mg; Se, $0.3 \mathrm{mg}$; I, $0.2 \mathrm{mg}$; retinyl acetate, 10,000 IU; cholecalciferol, 3,000 IU; DL- $\alpha$-tocopheryl acetate, $20 \mathrm{IU}$; menadione sodium bisulphate, $2 \mathrm{mg}$; thiamin, $2 \mathrm{mg}$; pyridoxine hydrochloride, $4 \mathrm{mg}$; cobalamin, $0.02 \mathrm{mg}$; calcium-Dpantothenate, $20 \mathrm{mg}$; nicotinic acid, $50 \mathrm{mg}$; folic acid, $1 \mathrm{mg}$; riboflavin 8 $\mathrm{mg}$; biotin, $0.2 \mathrm{mg}$.

${ }^{2}$ Values were calculated according to the MEn of feedstuffs for poultry provided by NRC (1994).

${ }^{3}$ Analyzed in duplicate.

${ }^{4}$ Below the level of detection.

were choline chloride (purity $\geq 98 \%$, Sinopharm Chemical Reagent Co., Ltd., Shanghai, China). The analyzed levels of dietary choline were $0,394,823,1,239$, and $1,743 \mathrm{mg} / \mathrm{kg}$ diet, respectively. Contents of methionine in basal diet were analyzed by ion-exchange chromatography with an amino acid analyzer (L-8900, Hitachi, Tokyo, Japan) after acid hydrolysis according to the method recommended by the Standardization Administration of China (2000). The analyzed methionine concentration in the basal diet was $0.28 \%$. Crude protein in the basal diet was determined by the Kjeldahl method (method 954.01; AOAC, 2000). All diets were firstly prepared in mash form and then all pelleted (2.5 $\mathrm{mm}$ in diameter).

\section{Measurements}

At $28 \mathrm{~d}$ of age, weight gain, feed intake and feed/gain of ducks from each pen were measured after $12 \mathrm{~h}$ of fasting. Feed intake and feed/gain were all corrected for mortality. In addition, the legs of all ducks from each pen were examined for incidence of perosis according to symptom 
descriptions of Evans et al. (1942). The symptoms of perosis were divided into four types: Enlarged hock joint; twisting, turning, or bowing leg; slipped tendon; crippled. When single or more symptoms were observed in one or both legs of ducks, the bird was considered to have perosis. The perosis of all ducks were examined by the same person every time.

\section{Statistical analysis}

Data were analyzed by two-way analysis of variance procedure of SAS (SAS Institute, 2003) with the pen being used as the experimental unit. Linear and quadratic polynomial contrasts were performed to determine the effects of dietary choline. The variability in the data was expressed as the standard error of the means and a probability level of $\mathrm{p}<0.05$ was considered to be statistically significant. In study, broken-line regression model analysis (Robbins et al., 2006) was used to estimate dietary choline requirement at each supplemental methionine level using the NLIN procedure of SAS. The model was as follows: $\mathrm{y}=$ $1+u(r-x)$, where $y=$ weight gain, $x=$ dietary choline level, $r$ $=$ choline requirement, $\mathrm{l}=$ the response at $\mathrm{x}=\mathrm{r}$ and $\mathrm{u}=$ the slope of model. In this model, $y=1$ when $x>r$. In addition, according to the statistical method suggested by Sterling et al. (2003), a t-test was used to determine if a difference existed for the choline requirements established at the two methionine levels.

\section{RESULTS AND DISCUSSION}

In previous studies, a diet containing a large percentage of corn starch and isolated soybean protein had been successfully used to determine the choline requirement and the availability of choline in feedstuffs for broilers (Molitoris and Baker, 1976; Pesti et al., 1981; Emmert and Baker, 1997). Therefore, in order to reduce choline content in the basal diet, purified diets containing corn starch and isolated soybean protein were used in this study as they contained little choline. The choline concentration in basal diet was analyzed by ion exchange chromatography, but it was not detected. The reason may be associated with the detection limit, precision, and recovery. So the choline concentration in basal diet was given as zero. Previous studies have used measurements of perosis and growth depression as the characteristic symptom of cholinedeficiency in ducks (Wen et al., 2014). In the present study, a lack of supplementation of choline caused perosis and depressed weight gain and feed intake, which indicated that the basal diet was choline deficient and was hence appropriate for estimation of choline requirements of Pekin ducks. Perosis caused by choline deficiency was reduced by increasing dietary choline level. The reason for perosis caused by choline deficiency may be that the content of phosphatidylcholine in the bone cell was decreased, because choline is a component of the membrane phospholipids (Hollenbeck, 2010). Additionally, choline deficiency could cause a decrease in choline kinase activity (Li et al., 2005); previous study has shown that choline kinase was required for normal endochondral bone formation (Li et al., 2014).

As shown in Table 2, supplementation of methionine significantly improved weight gain and feed intake and decreased feed/gain $(p<0.05)$. In poultry, this positive effect of methionine on growth performance has been shown by many researchers (Bornstein and Lipstein, 1964; Blair et al., 1986; Ohta and Ishibashi, 1995). In addition, supplementation of choline caused significant improvement in weight gain and feed intake (Table 2). This result is in accordance with a previous study in chickens by Ketola and Nesheim (1974), who reported that the addition of choline could improve the body weight gain of chicks either in the presence or absence of methionine supplementation. In this study, the data also indicated that methionine had a greater growth-promoting effect than choline because increasing dietary methionine significantly decreased feed/gain $(p<0.05)$, but it was not true for increasing choline. In chicks, excess choline was found to efficiently compensate for dietary methionine deficiency (Quillin et al., 1961; Pesti et al., 1980; Baker et al., 1983). This study found similar results. As shown in Table 2, at low methionine level, 1,743 $\mathrm{mg} / \mathrm{kg}$ choline could improve weight gain and feed intake further. However, at normal methionine level, weight gain and feed intake showed no increase at the $1,743 \mathrm{mg} / \mathrm{kg}$ choline level. It indicated that supplementation of choline in diets could alleviate the depression of weight gain and feed intake caused by methionine deficiency. Methionine plays an important role in poultry growth, and it is the firstlimiting amino acid in common poultry diets. The early growth of young birds is mainly due to the deposition of body protein, and feed intake is an important factor affecting body protein synthesis (Kita et al., 1996). Dietary methionine deficiency caused an imbalance in the diet's amino acid profile, which altered feed intake. This pattern in ducks has also been observed by Chen et al. (1991). This interaction between choline and methionine was also found in fish studies. In the absence of methionine, choline can provide a portion of the methionine requirement (Kasper et al., 2000; Wu and Davis, 2005). Because choline is a methyl donor and can donate a methyl to homocysteine to form methionine (Zeisel and Blusztajn, 1994), which was clearly shown by the interaction between choline and methionine in this study $(\mathrm{p}<0.05)$.

A linear increase in weight gain and feed intake was obtained as dietary choline was increased from 0 to 1,734 $\mathrm{mg} / \mathrm{kg}$ at $0.28 \%$ methionine level (Table 2). However, at $0.48 \%$ methionine level, weight gain and feed intake increased significantly as dietary choline increased from 0 
Table 2. Effect of dietary choline on growth performance and perosis of Pekin ducks from 7 to $28 \mathrm{~d}$ of age at two dietary methionine level ${ }^{1}$

\begin{tabular}{|c|c|c|c|c|c|c|}
\hline \multicolumn{3}{|l|}{ Dietary treatment } & \multirow{2}{*}{$\begin{array}{l}\text { Weight gain } \\
\text { (g/d/bird) }\end{array}$} & \multirow{2}{*}{$\begin{array}{l}\text { Feed intake } \\
\text { (g/d/bird) }\end{array}$} & \multirow{2}{*}{$\begin{array}{c}\text { Feed/gain } \\
(\mathrm{g}: \mathrm{g})\end{array}$} & \multirow{2}{*}{$\begin{array}{l}\text { Incidence of } \\
\text { perosis }^{3}(\%)\end{array}$} \\
\hline Dietary $\mathrm{Met}^{2}$ & Analyzed choline $^{2}$ & Calculated choline & & & & \\
\hline \multirow[t]{5}{*}{0.28} & 0 & 2 & $12.13^{\mathrm{e}}$ & $29.49^{\mathrm{e}}$ & 2.48 & 100 \\
\hline & 394 & 402 & $13.30^{\mathrm{e}}$ & $32.53^{\mathrm{de}}$ & 2.46 & 45 \\
\hline & 823 & 802 & $16.80^{\mathrm{cd}}$ & $39.89^{\mathrm{bc}}$ & 2.38 & 22 \\
\hline & 1,239 & 1,202 & $21.13^{\mathrm{ab}}$ & $49.23^{\mathrm{a}}$ & 2.35 & 5 \\
\hline & 1,743 & 1,602 & $22.17^{\mathrm{a}}$ & $50.82^{\mathrm{a}}$ & 2.32 & 0 \\
\hline \multirow[t]{5}{*}{0.48} & 0 & 2 & $15.94^{\mathrm{d}}$ & $35.96^{\mathrm{cd}}$ & 2.26 & 100 \\
\hline & 394 & 402 & $19.15^{\mathrm{bc}}$ & $42.01^{\mathrm{b}}$ & 2.20 & 15 \\
\hline & 823 & 802 & $22.05^{\mathrm{a}}$ & $50.58^{\mathrm{a}}$ & 2.31 & 4 \\
\hline & 1,239 & 1,202 & $23.11^{\mathrm{a}}$ & $52.17^{\mathrm{a}}$ & 2.30 & 0 \\
\hline & 1,743 & 1,602 & $22.99^{\mathrm{a}}$ & $51.38^{\mathrm{a}}$ & 2.26 & 0 \\
\hline Pooled SEM & & & 0.57 & 1.19 & 0.04 & \\
\hline \multicolumn{7}{|l|}{ Main effect } \\
\hline \multirow[t]{2}{*}{ Dietary Met level } & & 0.28 & $17.10^{\mathrm{b}}$ & $40.39^{\mathrm{b}}$ & $2.40^{\mathrm{b}}$ & \\
\hline & & 0.48 & $20.65^{\mathrm{a}}$ & $46.42^{\mathrm{a}}$ & $2.26^{\mathrm{a}}$ & \\
\hline Pooled SEM & & & 1.29 & 2.71 & 0.03 & \\
\hline \multirow[t]{5}{*}{ Dietary choline level } & & 0 & $14.04^{\mathrm{d}}$ & $32.73^{\mathrm{d}}$ & 2.38 & \\
\hline & & 394 & $16.22^{\mathrm{c}}$ & $37.27^{\mathrm{c}}$ & 2.33 & \\
\hline & & 823 & $19.43^{\mathrm{b}}$ & $45.24^{\mathrm{b}}$ & 2.35 & \\
\hline & & 239 & $22.12^{\mathrm{a}}$ & $50.70^{\mathrm{a}}$ & 2.32 & \\
\hline & &, 743 & $22.58^{\mathrm{a}}$ & $51.09^{\mathrm{a}}$ & 2.29 & \\
\hline Pooled SEM & & & 1.65 & 3.66 & 0.01 & \\
\hline \multicolumn{7}{|l|}{ Probability } \\
\hline Met & & & $<0.001$ & $<0.001$ & 0.048 & \\
\hline Choline & & & $<0.001$ & $<0.001$ & 0.896 & \\
\hline Met $\times$ choline & & & 0.046 & 0.045 & 0.908 & \\
\hline Choline linear & & & $<0.001$ & $<0.001$ & 0.584 & \\
\hline Choline quadratic & & & 0.028 & 0.104 & 0.974 & \\
\hline
\end{tabular}

SEM, standard error of the means.

${ }^{1}$ Values are the means of 6 replicates of 8 ducks. ${ }^{2}$ Analyzed value.

${ }^{3}$ Incidence of perosis $=$ the number of ducks with perosis per treatment/the total ducks number per treatment.

${ }^{\mathrm{a}-\mathrm{c}}$ Mean values in the same column with no common superscript differ significantly $(\mathrm{p}<0.05)$.

to $1,239 \mathrm{mg} / \mathrm{kg}$ and then reached a plateau at the ranges of dietary choline from 1,239 to $1,743 \mathrm{mg} / \mathrm{kg}$. Pekin ducks showed different growth response with increasing choline level at two methionine levels. This data indicates that more choline was needed by ducks at the low methionine level. Broken-line regression analysis has been used to estimate the choline requirements in broilers (Pesti et al., 1980), ducks (Wen et al., 2014), and fish (Mai et al., 2009; Jiang et al., 2012). Therefore, the choline requirements of ducks at two methionine levels were estimated by broken-line regression (Table 3). According to this regression, the choline requirements of White Pekin ducks for weight gain and feed intake were 1,472 and $1,424 \mathrm{mg} / \mathrm{kg}$ at $0.28 \%$ methionine level and 946 and $907 \mathrm{mg} / \mathrm{kg}$ at $0.48 \%$ methionine level, respectively (Table 3). The t-test showed that the choline requirement at $0.28 \%$ methionine level was

Table 3. Choline requirements for weight gain and feed intake at different supplemental methionine levels according to broken-line regression

\begin{tabular}{lccccc}
\hline Methionine level (\%) & Response criterion & Broken-line model & $\mathrm{p}$-value & $\mathrm{R}^{2}$ & ${\text { Choline requirement }(\mathrm{mg} / \mathrm{kg})^{1}}^{\mathrm{a}}$ \\
\hline 0.28 & Weight gain & $\mathrm{Y}=22.17-0.00738 \times(1,472-\mathrm{x})$ & 0.029 & 0.947 & $1,472 \pm 212^{\mathrm{a}}$ \\
& Feed intake & $\mathrm{Y}=50.82-0.0161 \times(1,424-\mathrm{x})$ & 0.024 & 0.959 & $1,424 \pm 187^{\mathrm{a}}$ \\
0.48 & Weight gain & $\mathrm{Y}=23.05-0.00741 \times(946-\mathrm{x})$ & 0.002 & 0.982 & $946 \pm 31^{\mathrm{b}}$ \\
& Feed intake & $\mathrm{Y}=51.775-0.0178 \times(907-\mathrm{x})$ & 0.005 & 0.981 & $907 \pm 48^{\mathrm{b}}$ \\
\hline
\end{tabular}

\footnotetext{
${ }^{1}$ It was expressed as requirement \pm standard error.

${ }^{a, b}$ Values in the same column with no common superscript differ significantly $(\mathrm{p}<0.05)$.
} 
much greater than the requirements of choline at $0.48 \%$ methionine level $(\mathrm{p}<0.05)$. Therefore, it was concluded that methionine deficiency markedly increased the choline requirements for ducks, and this reason for this may be that in the presence of low methionine there is greater reliance on any surplus choline above the requirement of the bird, as this can be oxidized to betaine which can provide methyl for conversion of homocysteine to methionine (Setoue et al., 2008).

\section{CONCLUSION}

In conclusion, choline deficiency could cause growth depression and perosis of starter Pekin ducks. In this study it was found that the choline requirements of male Pekin ducks from 7 to $28 \mathrm{~d}$ of age for weight gain and feed intake were 1,472 and $1,424 \mathrm{mg} / \mathrm{kg}$ at $0.28 \%$ methionine level and 946 and $907 \mathrm{mg} / \mathrm{kg}$ at $0.48 \%$ methionine level, respectively. It suggested the choline recommendations of starter Pekin ducks in semi-purified diet were $1,448 \mathrm{mg} / \mathrm{kg}$ at $0.28 \%$ methionine level and $927 \mathrm{mg} / \mathrm{kg}$ at $0.48 \%$ methionine level, respectively. Compared with the adequate methionine level, menthionine deficiency markedly increased the choline requirements of ducks.

\section{CONFLICT OF INTEREST}

We certify that there is no conflict of interest with any financial organization regarding the material discussed in the manuscript.

\section{ACKNOWLEDGMENTS}

This research was supported by the Earmarked fund for the Modern Waterfowl Industry Technology System of China (CARS-43) and the Agricultural Science and Technology Innovation Program (ASTIP-ISS09).

\section{REFERENCES}

AOAC (Association of Official Analytical Chemists). 2000 Official Methods of Analysis. 17th edn. Association of Official Analytical Chemists, Gaithersburg, MD, USA.

Baker, D., K. M. Halpin, G. Czarnecki, and C. Parsons. 1983. The choline-methionine interrelationship for growth of the chick. Poult. Sci. 62:133-137.

Bernard, R. and J. M. Demers. 1949. Lipotropic activity of choline, betaine, and methionine in ducklings. Can. J. Res. 27:281-289.

Blair, M. E., L. M. Potter, B. A. Bliss, and J. R. Shelton. 1986. Methionine, choline, and sulfate supplementation of practicaltype diets for young turkeys. Poult. Sci. 65:130-137.

Blusztajn, J. K. and R. J. Wurtman. 1983. Choline and cholinergic neurons. Science 221:614-620.

Bornstein, S. and B. Lipstein. 1964. Methionine supplementation of practical broiler rations: II. The value of added methionine in chick starter rations. Br. Poult. Sci. 5:175-186.

Chen, L. X., S. R. Zhang, and G. W. Yue. 1991. A study on the methionine requirement of Jianchang duck and Tianfu $\times$ Jianchang crossbred duck. J. Sichuan Agric. Univ. 4:630-642.

Emmert, J. L. and D. H. Baker. 1997. A chick bioassay approach for determining the bioavailable choline concentration in normal and overheated soybean meal, canola meal and peanut meal. J. Nutr. 127:745-752.

Evans, R. J., E. I. Robertson, M. Rhian, and L. A. Wilhelm. 1942. The development of perosis in turkey poults and its prevention. Poult. Sci. 21:422-429.

Harms, R. H. and R. D. Miles. 1984. Effect of supplemental methionine and potassium sulfate on the choline requirement of the turkey poult. Poult. Sci. 63:1464-1466.

Hollenbeck, C. B. 2010. The importance of being choline. J. Am. Diet. Assoc. 110:1162-1165.

Jiang, G. Z., M. Wang, W. B. Liu, G. F. Li, and Y. Qian. 2013. Dietary choline requirement for juvenile blunt snout bream, Megalobrama amblycephala. Aquac. Nutr. 19:499-505.

Kasper, C. S., M. R. White, and P. B. Brown. 2000. Choline is required by tilapia when methionine is not in excess. J. Nutr. 130:238-242.

Ketola, H. G. and M. C. Nesheim. 1974. Influence of dietary protein and methionine levels on the requirement for choline by chickens. J. Nutr. 104:1484-1489.

Kita, K., S. Matsunami, and J. Okumura. 1996. Relationship of protein synthesis to mRNA levels in the muscle of chicks under various nutritional conditions. J. Nutr. 126:1827-1832.

Li, Z., L. B. Agellon, and D. E. Vance. 2005. Phosphatidylcholine homeostasis and liver failure. J. Biol. Chem. 280:37798-37802.

Li, Z., G. Wu, R. B. Sher, Z. Khavandgar, M. Hermansson, G. A. Cox, M. R. Doschak, M. Murshed, F. Beier, and D. E. Vance. 2014. Choline kinase beta is required for normal endochondral bone formation. Biochim. Biophys. Acta 1840:2112-2122.

Lien, T. F. and D. F. Jan. 1999. The effect on the lipid metabolism of Tsaiya ducks when high levels of choline or methionine are added to the ducks' diet. Asian Australas. J. Anim. Sci. 12:1090-1095.

Mai, K., L. Xiao, Q. Ai, X. Wang, W. Xu, W. Zhang, Z. Liufu, and M. Ren. 2009. Dietary choline requirement for juvenile cobia, Rachycentron canadum. Aquaculture 289:124-128.

Miles, R. D., N. Ruiz, and R. H. Harms. 1983. The interrelationship between methionine, choline, and sulfate in broiler diets. Poult. Sci. 62:495-498.

Molitoris, B. A. and D. H. Baker. 1976. The choline requirement of broiler chicks during the seventh week of life. Poult. Sci. 55:220-224.

NRC (National Research Council). 1994. Nutrient Requirements of Poultry. 9th rev. edn. National Academy Press, Washington, DC, USA.

Ohta, Y. and T. Ishibashi. 1995. Effect of dietary glycine on reduced performance by deficient and excessive methionine in broilers. Nippon Kakin Gakkaishi 32:81-89.

Pesti, G. M., N. J. Benevenga, A. E. Harper, and M. L. Sunde. 1981. Factors influencing the assessment of the availability of choline in feedstuffs. Poult. Sci. 60:188-196. 
Pesti, G. M., A. E. Harper, and M. L. Sunde. 1980. Choline/methionine nutrition of starting broiler chicks. Three models for estimating the choline requirement with economic considerations. Poult. Sci. 59:1073-1081.

Quillin, E. C., G. F. Combs, R. D. Creek, and G. L. Romoser. 1961. Effect of choline on the methionine requirements of broiler chickens. Poult. Sci. 40:639-645.

Robbins, K. R., A. M. Saxton, and L. L. Southern. 2006 Estimation of nutrient requirements using broken-line regression analysis. J. Anim. Sci. 84:E155-E165.

SAS Institute. 2003. SAS User's Guide: Statistics Version 9.0. SAS Institute Inc., Cary, NC, USA.

Setoue, M., S. Ohuchi, T. Morita, and K. Sugiyama. 2008. Choline deprivation induces hyperhomocysteinemia in rats fed low methionine diets. J. Nutr. Sci. Vitaminol. 54:483-490.

Sterling, K. G., G. M. Pesti, and R. I. Bakalli. 2003. Performance of broiler chicks fed various levels of dietary lysine and crude protein. Poult. Sci. 82:1939-1947.
Standardization Administration of China. 2000. Determination of Amino Acids in Feeds. Standards Press of China, Beijing, China.

Wen, Z. G., J. Tang, S. S. Hou, Y. M. Guo, W. Huang, and M. Xie. 2014. Choline requirements of white Pekin ducks from hatch to 21 days of age. Poult. Sci. 93:3091-3096.

Wessler, I., H. Kilbinger, F. Bittinger, and C. J. Kirkpatrick. 2001. The biological role of non neuronal acetylcholine in plants and humans. Jpn. J. Pharmacol. 85:2-10.

Wu, G. and D. A. Davis. 2005. Interrelationship among methionine, choline, and betaine in channel catfish ictalurus punctutus. J. World Aquac. Soc. 36:337-345.

Zeisel, S. H. and J. K. Blusztajn. 1994. Choline and human nutrition. Annu. Rev. Nutr. 14:269-296.

Zhai, Q. H., X. F. Dong. J. M. Tong, Y. M. Guo, and Y. E. Bao. 2013. Long-term effects of choline on productive performance and egg quality of brown-egg laying hens. Poult. Sci. 92:18241829 . 